Note

\title{
Cytological aspects of incompatible and compatible interactions between rice, wheat and the blast pathogen Pyricularia oryzae
}

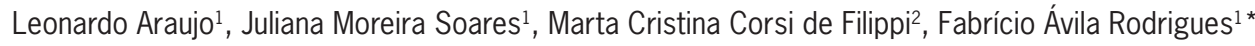

${ }^{1}$ Federal University of Viçosa - Dept. of Plant Pathology Lab. of Host-Parasit Interaction, Av. P.H. Rolfs, s/n - Campus Universitário - 36570-900 - Viçosa, MG - Brazil. ${ }^{2}$ Embrapa Rice and Beans, Rod. GO-462, km 12, C.P. 179 75375-000 - Santo Antônio de Goiás, GO - Brazil.

*Corresponding author <fabricio@ufv.br>

Edited by: Claudio Marcelo Gonçalves de Oliveira

Received April 21, 2015

Accepted August 04, 2015
ABSTRACT: Blast, caused by the fungus Pyricularia oryzae, is an important disease affecting rice and wheat yield worldwide. This study investigated the cytological aspects of incompatible (non-host resistance) and compatible (host resistance) rice- (R_Po) and wheat- (W_Po) Pyricularia oryzae isolate interactions. Inoculations of rice and wheat with the R_Po and W_Po isolates of $P$. oryzae, respectively, were expected to be compatible interactions (host resistance), whereas inoculations of rice and wheat with the W_Po and R_Po isolates of $P$. oryzae, respectively, were considered to be incompatible interactions (non-host resistance). For the compatible interactions (rice-R_Po and wheat-W_Po), fungal hyphae penetrated and colonized the epidermal cells and also invaded many neighboring cells. By contrast, in the case of the incompatible interactions (rice-W_Po and wheat-R_Po), fungal hyphae were not able to penetrate nor colonize the epidermal cells, but when penetration did occur, the hyphae were restricted to the first-invaded epidermal cell. The frequency of appressorial sites exhibiting infection hyphae within the epidermal cell underlying an appressorium was greater in the case of the compatible interactions. By contrast, unsuccessful penetrations with cytoplasmic granulation occurred with high frequency in the incompatible wheat-R_Po and rice-W_Po interactions and the number of necrotic epidermal cells underlying the appressorium was low for the rice-W_Po interaction as well as for the wheat-R_Po interaction, where no symptoms of necrosis were exhibited. However, the opposite was observed for the compatible interactions. The present study presents cytological features associated with incompatible and compatible rice- and wheat- $P$. oryzae interactions that may be useful to studies involving variability, coevolution, diagnosis, and regulation of quarantine or even in a rice or wheat breeding program whose aim is to transfer genes involved in non-host resistance to host resistance due to similarities in downstream mechanisms.

Keywords: Magnaporthe oryzae, Oryza sativa, Triticum aestivum L., blast disease, host resistance

\section{Introduction}

Rice (Oryza sativa L.) and wheat (Triticum aestivum L.) are the most important staple crops produced worldwide (Kohli et al., 2011; Talbot, 2003). The fungus Magnaporthe oryzae (asexual phase Pyricularia oryzae) is the causal agent of blast disease on gramineous plants and poses a threat to world food security (Kohli et al., 2011; Talbot, 2003; Tosa et al., 2006; Valent and Chumley, 1991).

P. oryzae is part of a species complex composed of fungal populations that show specialization toward different hosts such as barley, millet, oat rice and wheat (Couch et al., 2005; Valent and Chumley, 1991). Isolates that are pathogenic on cultivated cereals such as rice and wheat belong to the species $P$. oryzae, while isolates that are pathogenic on wild grasses belong to the species $P$. grisea (Couch and Kohn, 2002). However, isolates from each crop are almost exclusively pathogenic on their original host genus (Tosa et al., 2006; Valent and Chumley, 1991).

In natural ecosystems, hosts and pathogens are engaged in a never-ending struggle, where hosts evolve by escaping from pathogen infection and pathogens by by-passing the host defense responses (McDonald and Linde, 2002). This coevolution, which largely determines the host-pathogen interactions, co-speciation, host-shift speciation and host jump, plays a key role in the adaptation of pathogens to new plant species (Gill et al., 2015). The rice- and wheat-P. oryzae interactions follow the gene-for-gene interaction proposed by Flor (1971), in which a specific race of $P$. oryzae carrying an avirulence gene is incompatible with a certain cultivar that contains the respective resistance gene (host resistance) (Liu et al., 2007; Zhan et al., 2008). Non-host resistance is usually more complex than host resistance, due to the involvement of multiple pathways (Gill et al., 2015). According to McDonald and Linde (2002), agroecosystems that are based on the widespread deployment of single, major resistance genes place strong directional selection on the pathogen population, which consequently enhances the risk that plants will lose their resistance to diseases. In contrast, non-host resistance is not pathogen-race-specific and, therefore, decreases the risk of resistance suppression by the pathogens (Gill et al., 2015).

Considering the importance of studying both incompatible (non-host resistance) and compatible (host 
resistance) host-parasite interactions to the better understanding of the defense mechanisms mounted by the hosts to cope with pathogen infection and, thus, secure new strategies for disease control, this study aimed to investigate the cytological aspects of rice- and wheat- $P$. oryzae isolate interactions.

\section{Materials and Methods}

\section{Rice and wheat plant growth}

Plastic pots (12-cm diameter) were filled with $2 \mathrm{~kg}$ of soil and sand, in a 3:1 proportion, and fertilized with $100 \mathrm{~mL}$ of a nutrient solution containing $\left(\mathrm{mg} \mathrm{kg}^{-1}\right): 100$ $\mathrm{N}, 300 \mathrm{P}, 150 \mathrm{~K}, 85 \mathrm{Ca}, 70 \mathrm{Mg}, 40 \mathrm{~S}, 0.81 \mathrm{~B}, 1.33 \mathrm{Cu}, 3.66$ Mn, 0.15 Mo and 4.00 Zn (Rodrigues et al., 2003) two days before sowing. Rice and wheat seeds from the cultivars Metica-1 and BR-208, respectively, were surface sterilized in $10 \%(\mathrm{v} / \mathrm{v}) \mathrm{NaOCl}$ for $1.5 \mathrm{~min}$, rinsed in sterilized water for $3 \mathrm{~min}$ and sown at a rate of six seeds per pot. Five days after the seedlings emerged, each pot was thinned to two plants. The plants received $25 \mathrm{~mL}$ of the nutrient solution every week and were watered daily.

\section{Inoculation of plants with $\boldsymbol{P}$. oryzae}

Monosporic isolates of P. oryzae Py8888 (= R_Po) (Santo Antônio de Goiás, Goiás, Brazil, latitude -16.4855, longitude -49.3089, 16²9'8" S, 49¹8'32" W) and Py1050 (= W_Po) (Formoso do Araguaia, Tocantins, Brazil, latitude -11.7957, longitude - 49.5311, 11 ${ }^{\circ} 47^{\prime} 45^{\prime \prime} \mathrm{S}$, $49^{\circ} 31^{\prime} 52^{\prime \prime} \mathrm{W}$ ) were obtained from the leaves of rice (cv. Metica-1) and wheat (cv. BR 208) plants, respectively, exhibiting typical symptoms of blast. The cultivars Metica-1 and BR-208 have no known major or minor gene(s) for resistance to the $\mathrm{R} \_P o$ and $\mathrm{W} \_P o$ races of $P$. oryzae used in this study. Considering that rice- and wheat-derived populations of $P$. oryzae are described as genetically distinct and host specific (Bruno and Urashima, 2001; Maciel et al., 2014; Valent and Chumley, 1991), the inoculation of rice with the $\mathrm{R} \_$Po isolate and wheat with the W_Po isolate were expected to be compatible interactions (host resistance), whereas the inoculations of rice with the $\mathrm{W} \_P o$ isolate and wheat with the $\mathrm{R} \_$Po isolate were expected to be incompatible interactions (non-host resistance).

The two fungal isolates were preserved on filter paper at $-80^{\circ} \mathrm{C}$ (Dhingra and Sinclair, 1995). Pieces of filter paper containing fungal mycelia were transferred to Petri dishes containing potato-dextrose-agar (PDA). After three days, PDA plugs containing fungal mycelia were transferred to Petri dishes containing oat medium. The Petri dishes were maintained in a growth chamber at 25 ${ }^{\circ} \mathrm{C}$ with a 12-h photoperiod for 10 days. After this period, conidia were carefully removed from the Petri dishes using a soft bristle brush and water containing gelatin (1 $\% \mathrm{w} / \mathrm{v})$. The conidial suspension was calibrated using a hemacytometer to obtain a concentration of $1 \times 10^{5}$ conidia $\mathrm{mL}^{-1}$. The conidial suspension was sprayed on the adaxial surface of the leaves of rice and wheat plants at 30 days after emergence using an atomizer (Chicago, USA). The rice and wheat plants were inoculated separately with the conidial suspension of each $P$. oryzae isolate.

Immediately after inoculation, the plants were transferred to a growth chamber with a temperature of $25 \pm 2{ }^{\circ} \mathrm{C}$ and a relative humidity of $90 \pm 5 \%$ and were subjected to an initial $24 \mathrm{~h}$ dark period. After this period, the plants were transferred to a plastic mist growth chamber (MGC) inside a greenhouse for the duration of the experiments. The MGC was constructed of wood (2-m wide, 1.5-m high and 5-m long, covered with $100-\mu \mathrm{m}$-thick transparent plastic). The temperature inside of the MGC ranged from $25 \pm 2{ }^{\circ} \mathrm{C}$ (day) to $20 \pm$ $2{ }^{\circ} \mathrm{C}$ (night). The relative humidity was maintained at $92 \pm 3 \%$ using a misting system (model NEB-100, São Paulo, Brazil), which sprayed mist every $30 \mathrm{~min}$ above the plant canopies. Relative humidity and temperature were measured with a thermo-hygrograph (TH-508, São Paulo, Brazil). The maximum natural photon flux density at plant canopy height was approximately $950 \mu \mathrm{mol}$ $\mathrm{m}^{-2} \mathrm{~s}^{-1}$.

\section{Processing the infected leaf fragments for micro-} scopic studies

A total of 30 to 40 leaf fragments $\left(1 \mathrm{~cm}^{2}\right)$ were randomly collected from leaves of two plants per replication and treatment at 12, 24, 36, 48, 72 and 96 hours after inoculation (hai) with the two isolates of P. oryzae. Leaf fragments were fixed and decolorized in $70 \%$ ethanol $(\mathrm{v} / \mathrm{v})$ for approximately 7 days before being cleared for three weeks in saturated chloral hydrate solution (50 g $\mathrm{mL}^{-1}$ ) according to Rodrigues et al., (2005). Cleared leaf pieces were mounted adaxial side up on glass slides containing 2 drops of modified Hoyer's mounting medium (Cunningham, 1972).

Fifty appressorial sites per replication and treatment were randomly examined in detail to determine the fungal development index (FDI) within the epidermal cell(s), cell responses to fungal penetration and the number of necrotic cells (NNC). The FDI within epidermal cell(s) of each appressorial site was determined based on the infection index developed by Takahashi (1956) and modified by Rodrigues et al., (2005). The FDI for each infected cell ranged from 0 to 4 where each note corresponded to a specific event: 0 - conidium has formed an appressorium, but the infection hyphae has not been observed within the epidermal cell, 0.5 - the infection hyphae within the epidermal cell has a length shorter than the diameter of the appressorium $(\approx 1 \mathrm{~mm})$, 1 - the infection hyphae has a length greater than two to five times the diameter of the appressorium, 2 - infection hyphae has a length greater than five times the diameter of the appressorium, but without any branching, 3 - the infection hyphae has elongated within the epidermal cell forming a few branches and 4 - fully developed infection hyphae within epidermal cell without extension to neighboring epidermal cells. FDI values greater than 
four corresponded to the sum of infection indexes observed in the first penetrated epidermal cell and secondarily, colonized neighboring cells.

The cellular responses to $P$. oryzae penetration were grouped into three categories according to Rodrigues et al., (2005): A - unsuccessful penetration (absence of infection hyphae within epidermal cell underlying the appressorium), B - successful penetration (infection hyphae within the epidermal cell and absence of cytoplasmic granulation) and C - successful penetration (infection hyphae within the epidermal cell associated with intense cytoplasmic granulation). The NNC was determined on the epidermal cells with browning for the fifty appressorial sites according to Rodrigues et al., (2005). The images of the details regarding the FDI, cell responses to fungal penetration and NNC were acquired digitally with a camera, model AxioCam HR (Jena, Thuringia, Germany) in a light microscope equipped with differential interference contrast and further processed with the AXION VISION software v. 4.8.1.

\section{Experimental design and statistical analysis}

A factorial experiment consisting of two crops (rice and wheat) and two P. oryzae isolates (R_Po and W_Po) was arranged in a completely randomized design with ten replications. Each replication corresponded to a plastic pot with two plants. The experiment was repeated once. Data were submitted to analysis of variance and the treatment means were compared using the $t$-test $(p$ $\leq 0.05$ ) using the SAS software (Release 8.02 Level 02M0 for Windows; SAS Institute, Inc., 1989, Cary, NC, USA).

\section{Results}

\section{FDI}

The infection hyphae of both isolates of $P$. oryzae were observed in the first penetrated epidermal cell of rice and wheat plants at 48 hai (Figure 1). At 72 and 96 hai with the W_Po isolate, the FDI values for wheat (compatible interaction) were 295 and $283 \%$ higher, respectively, than those for rice (incompatible interaction) (Figure 1). At 96 hai, the fungal hyphae of the W_Po isolate grew successfully and formed an extensively branched mycelium in the first-invaded epidermal cell and invaded many neighboring cells of the wheat leaf tissue (Figure 2). On the rice leaf fragments, the fungal hyphae of the W_Po isolate were restricted to the first-invaded epidermal cell (Figure 2). At 48, 72 and 96 hai with the R_Po isolate, the FDI values were 400, 500 and 1,460 \% greater, respectively, for rice (compatible interaction) in comparison to wheat (incompatible interaction) (Figure 1). At 96 hai, the fungal hyphae of the R_Po isolate grew and formed an extensively branched mycelium in the first-invaded epidermal cell and invaded neighboring cells of the rice leaf fragments (Figure 2). In contrast, appressoria of the R_Po isolate were formed on the wheat leaf fragments, but the fungus did not develop infection hyphae nor branched mycelia in the epidermal cells (Figure 2).

\section{Frequency of cellular responses}

Only at 48 hai did the fungal hyphae of both isolates of $P$. oryzae penetrate the leaf fragments of the rice and wheat plants (Figure 3). From 48 to 96 hai, many appressorial sites examined exhibited a type $B$ reaction (successful penetration: infection hyphae within the epidermal cell and absence of cytoplasmic granulation) on the leaf fragments from both rice and wheat regardless of the fungal isolate. However, higher frequencies were observed in the compatible interactions (Figure 3). In the incompatible interaction between wheat and the R_Po isolate the frequency of the type A reaction (unsuccessful penetration: absence of infection hyphae within the epidermal cell underlying the appressorium) was high during the time course evaluated (Figure 3). The type $\mathrm{C}$ reaction was not observed on the leaf fragments of wheat plants inoculated with either isolate of $P$. oryzae (Figure 3 ). On rice, the type $\mathrm{C}$ reaction (successful penetration: infection

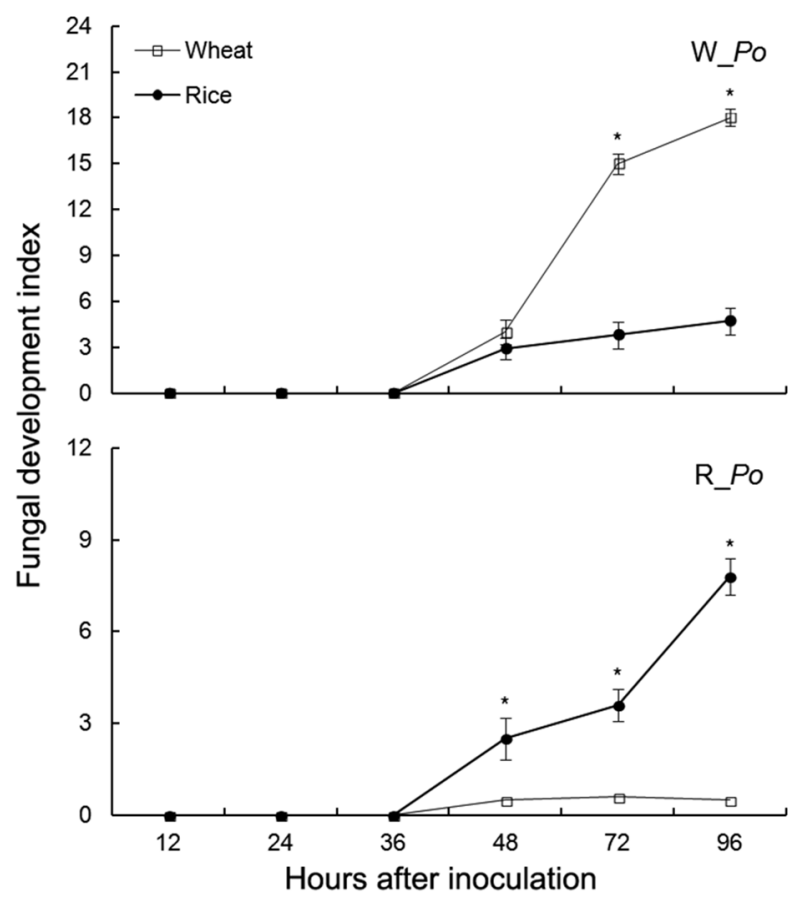

Figure 1 - Fungal development index within the adaxial epidermal cells of the leaves of wheat and rice plants at different hours after inoculation with the W_Po and R_Po isolates of Pyricularia oryzae. The FDI within epidermal cell(s) of each appressorial site was determined based on the fungal infection events developed by Takahashi (1956). Compatible interactions (host resistance): inoculations of rice leaves with the R_Po isolate and wheat leaves with the W_Po isolate. Incompatible interactions (non-host resistance): inoculations of rice leaves with the W_Po isolate and wheat leaves with the R_Po isolate. Means of the wheat and rice treatments followed by an asterisk (") are different $(p \leq 0.05)$ based on the t-test. Error bars represent the standard deviation of the means. $n=10$. 
hyphae within the epidermal cell associated with cytoplasmic granulation) was obtained only when the leaves were inoculated with the W_Po isolate (incompatible interaction) (Figure 3).

\section{NNC}

The epidermal cells at the appressorial sites examined became necrotic at 48 hai on the leaf fragments from both rice and wheat plants regardless of the fungal isolate (Figure 4). Differences $(p \leq 0.05)$ between the rice and wheat plants inoculated with the W_Po and R_Po isolates of $P$. oryzae occurred at 48 , 72 and 96 hai (Figure 4). At 48, 72 and 96 hai with the W_Po isolate, the NNC on the leaf fragments from the wheat plants (compatible interaction) was 103, 86 and $98 \%$ greater, respectively, in comparison to the leaf fragments from the rice plants (incompatible interaction) (Figure 4). In contrast, there was no sign of necrotic cells on the leaf fragments from the wheat plants inoculated with the R_Po isolate (incompatible interaction), whereas on the leaf fragments from the rice plants (compatible interaction), the NNC increased from 48 to 96 hai (Figure 4).

\section{Discussion}

As far as the authors know, this is the first study to assess the cytological features associated with incompatible (non-host resistance) and compatible (host resistance) rice- and wheat- $P$. oryzae isolates interactions. In the compatible interactions (rice-isolate R_Po and wheatisolate W_Pol, the fungal hyphae penetrated and colonized the epidermal cells and also invaded many neighboring cells. In contrast, in the incompatible interactions (rice-isolate W_Po and wheat-isolate $R \_P o$ ), the fungal hyphae were not able to penetrate nor colonize the cells, or when penetration did occur, the hyphae were restricted to the first-invaded epidermal cell. The rice- and wheat- $P$. oryzae interactions probably follow the genefor-gene interaction proposed by Flor (1971), in which the resistance genes are predicted to encode cytoplasmic proteins with a centrally located nucleotide-binding site and a carboxy terminal leucine-rich repeat (LRR) region (Liu et al., 2007; Zhan et al., 2008). In contrast, nonhost resistance is believed to be a multi-gene trait and more durable (Gill et al., 2015). Despite their classification into two classes, host and non-host resistance share
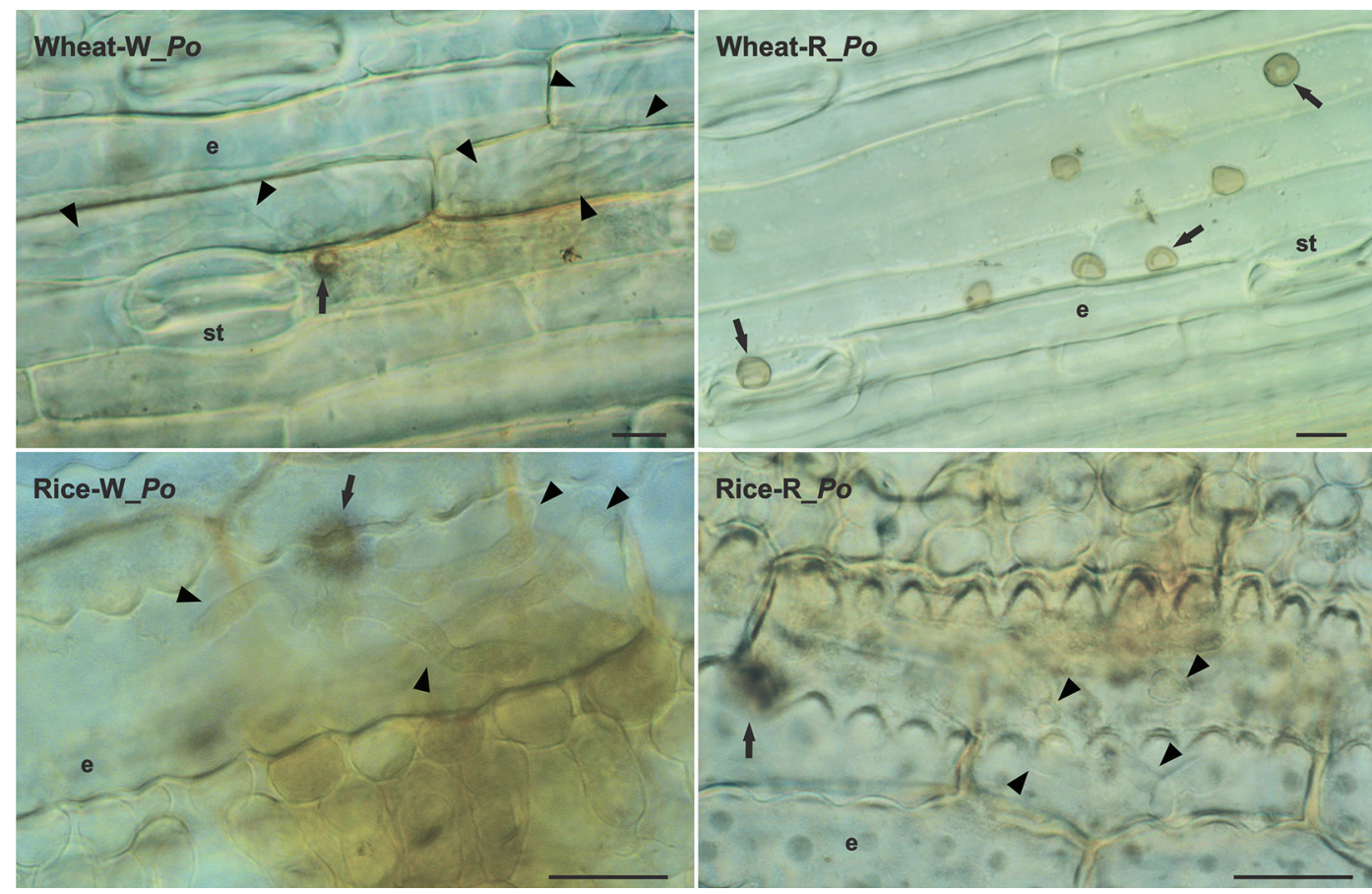

Figure 2 - Differential interference contrast microscopy of cleared leaves of wheat and rice plants at 96 hours after inoculation with the W_Po and R_Po isolates of Pyricularia oryzae. Compatible interactions (host resistance): inoculations of rice leaves with the R_Po isolate and wheat leaves with the W_Po isolate. Incompatible interactions (non-host resistance): inoculations of rice leaves with the W_Po isolate and wheat leaves with the R_Po isolate. In compatible interactions wheat-W_Po and rice-R_Po an appressorium (arrow) of P. oryzae formed an infection hypha that branched (arrowhead) and colonized the first-invaded epidermal cell and reached some neighboring cells afterwards. In incompatible interaction wheat-R_Po, appressoria (arrow) of $P$. oryzae were formed, but the fungus did not develop any detectable infection hyphae nor branched mycelium in the epidermal cell. Whereas, in incompatible interaction rice-W_Po, fungal hyphae that originated from an appressorium (arrow) within an epidermal cell showed limited growth (arrowhead). Epidermis (e) and stomata (st). Scale bars $=20 \mu \mathrm{m}$. 

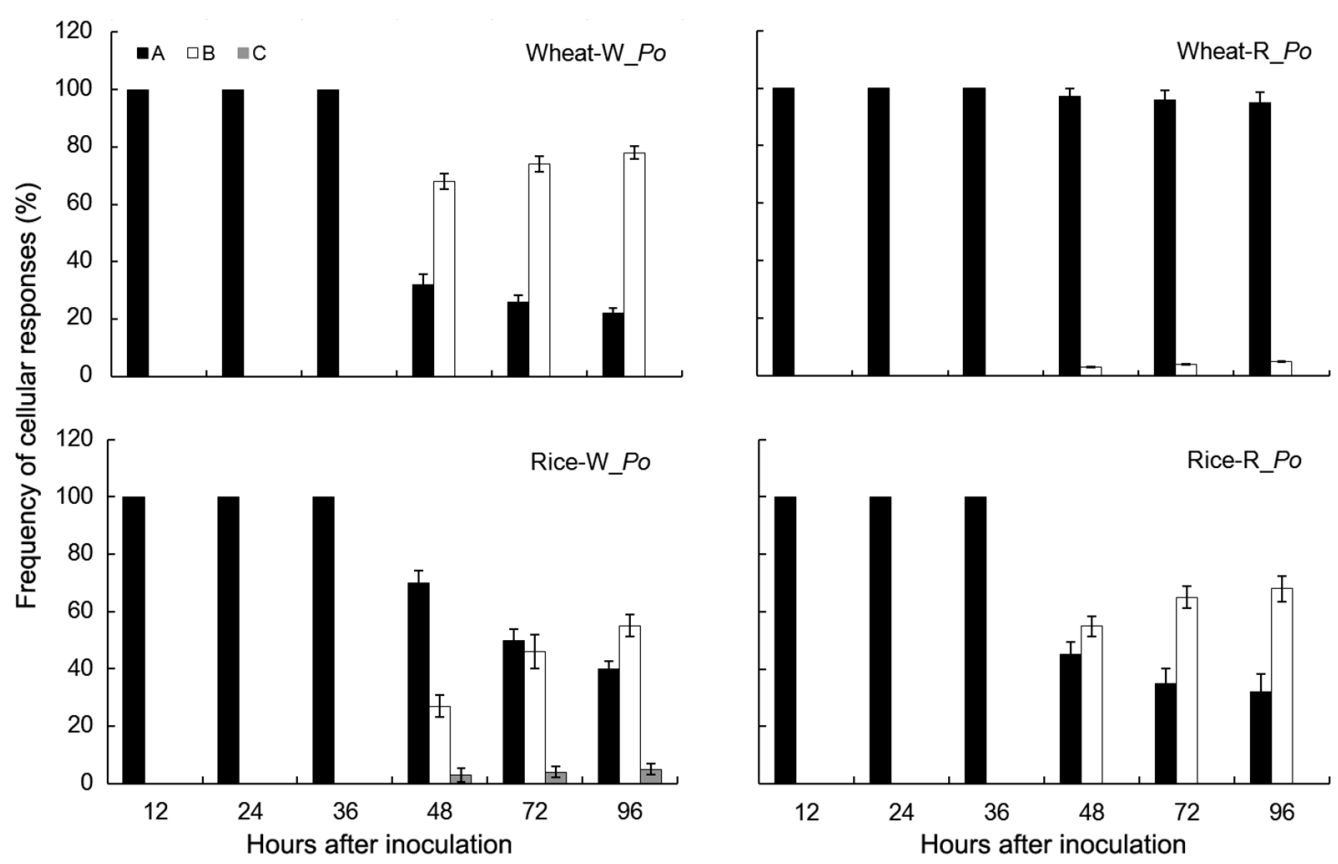

Figure 3 - Categories of cellular responses occurring in the adaxial epidermal cell(s) of leaves from wheat and rice plants at different hours after inoculation with the W_Po and R_Po isolates of Pyricularia oryzae. Cellular responses were grouped into the following categories: A - unsuccessful penetration (absence of infection hyphae within the epidermal cell underlying the appressorium), B - successful penetration (infection hyphae within the epidermal cell and absence of cytoplasmic granulation) and C - successful penetration (infection hyphae within the epidermal cell associated with cytoplasmic granulation). Compatible interactions (host resistance): inoculations of rice leaves with the R_Po isolate and wheat leaves with the W_Po isolate. Incompatible interactions (non-host resistance): inoculations of rice leaves with the W_Po isolate and wheat leaves with the R_Po isolate. Error bars represent the standard deviation of the means. $n=10$.

more similarities in their mechanisms and process of resistance (Gill et al., 2015). According to Rodrigues et al., (2005) and Sousa et al., (2013), in compatible rice- and wheat- $P$. oryzae interactions, fungal hyphae extensively penetrated and colonized the epidermal and mesophyll cells of the leaf tissue. Rodrigues et al., (2005) reported that in an incompatible rice-P. oryzae interaction, fungal hyphae were restricted to the first penetrated epidermal cell and appeared to have died at 48 hai due to the intense deposition of phenolic-like compounds. Tufan et al., (2009) showed that fungal hyphae from an avirulent isolate of $P$. oryzae were restricted to the first-invaded epidermal cell of wheat leaves and were rarely observed colonizing the neighboring cells. By contrast, fungal hyphae from a virulent isolate of $P$. oryzae were able to colonize the neighboring cells of the first invaded cell (Tufan et al., 2009). The direct and or indirect recognition of an avirulence protein by a resistance protein is followed by a strong defense signaling response (cytoplasmic aggregation, nucleus movement, production of reactive oxygen species, deposition of phenolics and tissue lignification) that limits further pathogen growth from the penetrated cell (Gill et al., 2015). In the present study, the reduced fungal colonization on the rice leaf cells in the incompatible interaction of the rice-isolate W_Po, can possibly be attributed to the recognition of one or more avirulence proteins by the protein/or proteins produced by a major resistance gene/or genes that probably regulates a non-host resistance response. On the other hand, in the incompatible interaction of the wheat-isolate $\mathrm{R} \_P o$, a host defense response at the appressorial level could have contributed to the absence of fungal hyphae within the epidermal cell.

The frequency of appressorial sites exhibiting infection hyphae within the epidermal cell underlying the appressorium (type $B$ reaction) was greater for the compatible interactions. In contrast, a high frequency of unsuccessful penetrations (type A reaction) and cytoplasmic granulation (type $\mathrm{C}$ reaction) occurred in the incompatible wheat-R_Po and rice-W_Po interactions, respectively. At the cellular level, both non-host and host resistance are associated with similar cellular responses, but with different intensities (Gill et al., 2015). Tufan et al., (2009) reported that avirulent isolates of $P$. oryzae were unable to infect wheat genotypes carrying resistance genes. The beginning of an incompatible wheat- $P$. oryzae interaction was marked by the autofluorescence of halo (papillae-like structure) visualized at some appressorial sites, whereas hyphae were noticed at some appressorial sites. Rodrigues et al., (2005) showed that for an incompatible rice- $P$. oryzae interaction, the epidermal cells reacted to fungal ingress through the granula- 


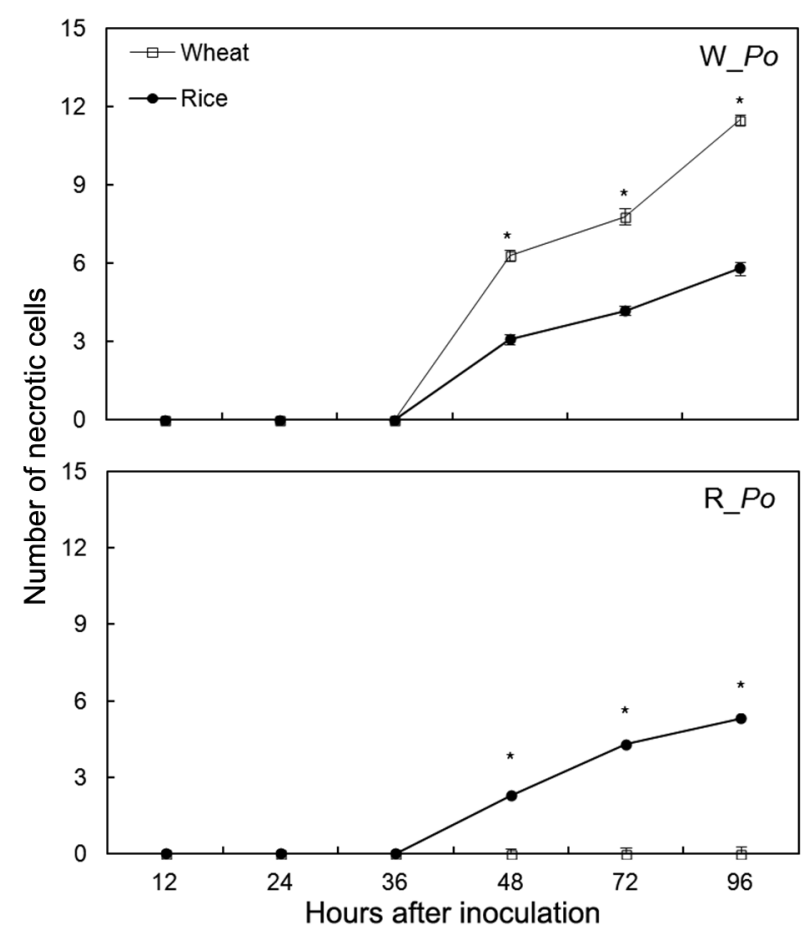

Figure 4 - Number of necrotic leaf epidermal cells of wheat and rice plants at different hours after inoculation with the W_Po and R_Po isolates of Pyricularia oryzae. Compatible interactions (host resistance): inoculations of rice leaves with the $R \_P o$ isolate and wheat leaves with the W_Po isolate. Incompatible interactions (nonhost resistance): inoculations of rice leaves with the W_Po isolate and wheat leaves with the R_Po isolate. Means of the wheat and rice treatments followed by an asterisk ( $\left.{ }^{*}\right)$ are different $(p \leq 0.05)$ based on the t-test. Error bars represent the standard deviation of the means. $n=10$.

tion of the cytoplasm, and a bright autofluorescence of the epidermal cell walls or the entire penetrated cell was observed. In the present study, the cellular defense for both incompatible interactions (non-host resistance: riceisolate $\mathrm{W} \_P o$ and wheat-isolate $\mathrm{R} \_P o$ ) seemed stronger compared to compatible interactions (host resistance: rice-isolate $R \_P o$ and wheat-isolate $\mathrm{W} \_P o$ ).

The NNC at the appressorium sites for the riceW_Po interaction was low or did not indicate any sign of tissue necrosis in the wheat-R_Po interaction. However, the opposite was observed in the compatible interactions. According to Rodrigues et al., (2003, 2005), necrosis must be triggered in a compatible rice- $P$. oryzae interaction in order for the fungus to obtain the necessary nutrients to fully colonize the leaf tissue and to sporulate. The reactions of different rice cultivars carrying different resistance genes and inoculated with avirulent and virulent isolates of $P$. oryzae were investigated at the microscopic level by Faivre-Rampant et al., (2008). According to these authors, the following cell reactions were noticed in the incompatible interactions: appressoria were formed without any visible cellular response in the epidermal cell or in the neighboring epidermal or mesophyll cells (absence of a hypersensitive response (HR)); appressoria were formed in the epidermal cells and the whole cells became necrotic (HR in a single cell) and appressoria were formed and fungal hyphae penetrated the epidermal cell and colonized the neighboring cells that became necrotic (multiple cells showing HR). In the compatible interactions, the predominant cellular reaction was noted as appressorium formation, and the fungal hyphae in the first penetrated epidermal cell massively colonized the neighboring cells afterwards (Faivre-Rampant et al., 2008). In the present study, the higher number of necrotic epidermal cells in the compatible interactions was the result of unlimited fungal growth within the leaf tissues in contrast to the limited fungal growth in the incompatible interaction probably due to the HR reaction or other defense response.

The present study presents cytological features associated with incompatible (non-host resistance) and compatible (host resistance) rice- and wheat- $P$. oryzae isolate interactions that may be useful in studies involving variability, coevolution, diagnosis, and regulation of blast quarantine or even in a rice or wheat breeding program aimed at transfering genes involved in non-host resistance to host resistance due to similarities in downstream mechanisms (plant immune response).

\section{Acknowledgments}

The fourth author thanks the Brazilian National Council for Scientific and Technological Development (CNPq) for his fellowship. The first author was supported by the CNPq (PDJ Scholarship, Process 502252/20138). This study was supported by grants from $\mathrm{CNPq}$ and the Minas Gerais State Foundation for Research Support (FAPEMIG) to the fourth author.

\section{References}

Bruno, A.C.; Urashima, A.S. 2001. Sexual relationship between Magnaporthe grisea from wheat and from other hosts. Fitopatologia Brasileira 26: 21-26 (in Portuguese, with abstract in English).

Couch, B.C.; Fudal, I.; Lebrun, M.-H.; Tharreau, D.; Valent, B.; Van Kim, P.; Nottéghem, J.-L.; Kohn, L.M. 2005. Origins of hostspecific populations of the blast pathogen Magnaporthe oryzae in crop domestication with subsequent expansion of pandemic clones on rice and weeds of rice. Genetics 170: 613-630.

Cunningham, J.L. 1972. A miracle mounting fluid for permanent whole-mounts of microfungi. Mycologia 64: 906-911.

Dhingra, O.D.; Sinclair, J.B. 1995. Basic Plant Pathology Methods. Boca Raton, Lewis Publisher.

Faivre-Rampant, O.; Thomas, J.; Allègre, M.; Morel, J.-B.; Tharreau, D.; Nottéghem, J.-L.; Lebrun, M.-H.; Schaffrath, U.; Piffanelli, P. 2008. Characterization of the model system rice-Magnaporthe for the study of nonhost resistance in cereals. New Phytologist 180: 899-910. 
Flor, H.H. 1971. Current status of the gene-for-gene concept. Annual Review of Phytopathology 9: 275-296.

Gill, U.S.; Lee, S.; Mysore, K.S. 2015. Host versus nonhost resistance: distinct wars with similar arsenals. Phytopathology 105: 580-587.

Kohli, M.M.; Mehta, Y.R.; Guzman, E.; Viedma, L.; Cubilla, L.E. 2011. Pyriculariablast - a threat to wheat cultivation. Czech Journal of Genetics and Plant Breeding 47: 130-134.

Liu, J.; Liu, X.; Dai, L.; Wang, G. 2007. Recent progress in elucidating the structure, function and evolution of disease resistance genes in plants. Journal of Genetics and Genomics 34: 765-776.

Maciel, J.L.N.; Ceresini, P.C.; Castroagudin, V.L.; Kema, G.H.J.; McDonald, B.A. 2014. Population structure and pathotype diversity of the wheat blast pathogen Magnaporthe oryzae 25 years after its emergence in Brazil. Phytopathology 104: 95107

McDonald, B.A.; Linde, C. 2002. The population genetics of plant pathogens and breeding strategies for durable resistance. Euphytica 124: 163-180.

Rodrigues, F.A.; Benhamou, N.; Datnoff, L.E.; Jones, J.B.; Bélanger, R.R. 2003. Ultrastructural and cytochemical aspects of silicon-mediated rice blast resistance. Phytopathology 93: 535-546.

Rodrigues, F.A.; Jurick II, W.M.; Datnoff, L.E.; Jones, J.B.; Rollins, J.A. 2005. Silicon influences cytological and molecular events in compatible and incompatible rice-Magnaporthe grisea interactions. Physiological and Molecular Plant Pathology 66: 144-159.
Sousa, R.S.; Rodrigues, F.A.; Schurt, D.A.; Souza, N.F.A.; Cruz M.F.A. 2013. Cytological aspects of the infection process of Pyricularia oryzae on leaves of wheat plants supplied with silicon. Tropical Plant Pathology 38: 472-477.

Takahashi, Y. 1956. Studies on the mechanism of resistance of rice plants to Piricularia oryzae. II. Pathological changes microscopically observed in host cells in which fungus hyphae do not grow well. Yamagata University Agricultural Science Bulletin 2: 37-51.

Talbot, N.J. 2003. On the trail of a cereal killer: exploring the biology of Magnaporthe grisea. Annual Review of Microbiology 57: $177-202$.

Tosa, Y.; Tamba, H.; Tanaka, K.; Mayama, S. 2006. Genetic analysis of host species specificity of Magnaporthe oryzae isolates from rice and wheat. Phytopathology 96: 480-484.

Tufan, H.A.; McGrann, G.R.D.; Magusin, A.; Morel, J.-B.; Miché, L.; Boyd, L.A. 2009. Wheat blast: histopathology and transcriptome reprogramming in response to adapted and nonadapted Magnaporthe isolates. New Phytologist 184: 473484.

Valent, B.; Chumley, F.G. 1991. Molecular genetic analysis of the rice blast fungus, Magnaporthe grisea. Annual Review of Phytopathology 29: 443-467.

Zhan, S.W.; Mayama, S.; Tosa, Y. 2008. Identification of two genes for resistance to Triticum isolates of Magnaporthe oryzae in wheat. Genome 51: 216-221. 